\section{Systematic assessment of the training needs of health library staff}

\author{
Christine Urquhart, Siân \\ Spink, Rhian Thomas, \\ Jane Durbin
}

Contact address: Department of Information Studies, University of Wales Aberystwyth, Aberystwyth SY23 3AS, tel.01970-622162, email cju@aber.ac.uk

\begin{abstract}
The aim of research conducted for the National Library for Health was to identify what type of training was required, and how the training should be delivered. The article describes the systematic approach used to collate and synthesise the findings of published and unpublished studies (1999-2004) on the training needs of health library staff. The research included two workshops with health library staff to discuss the interim findings (in late 2004). The results showed that health librarians required specialist skills in information retrieval and knowledge management, as well as more advanced research related skills. The conclusions note the need for an agreed competency framework, but also some vision of the capabilities of librarians in the future. For librarians working outside the health sector, the findings indicate that the profession needs to offer career advancement through specialist routes as well as through the managerial route.
\end{abstract}

\section{Acknowledgements}

The authors thank all the participants who contributed to the survey work or the focus groups for this research. We thank the South Yorkshire Workforce Development Confederation, and the National Library for Health for their financial support. Valerie

Monaghan provided invaluable support to the research team for the South Yorkshire training needs analysis, as did Alison Turner for the CPD study for the National Library for Health.

\section{Introduction}

In 2004, the Department of Information Studies, University of Wales Aberystwyth was asked to undertake a training needs analysis of the health library staff in the South Yorkshire area (Urquhart, Durbin \& Spink, 2004) and later, an overview survey of the training needs analysis of health library staff in England for the National Library for Health (Urquhart, Spink \& Thomas, 2005). This paper describes the approach taken to the research for the National Library for Health, and discusses the main findings, with emphasis on the implications for the continuing professional development of all library staff.

\section{Background}

In the health sector, library staff are now included within the health informatics grouping. Recently there have been several workforce development initiatives attempting to delineate the skills and competencies of staff within this grouping. A project to develop national occupational standards for those working in health informatics arose from the Department of Health human resources strategy (Department of Health, 2002) for those working in health informatics. An NHS Information Authority project to develop national occupational standards for ICT staff was integrated into the project to develop occupational standards for health informatics staff. The project (Christie, 2004) sets out the main health informatics staff groups as:

- Knowledge management staff

- Information management staff

- Health informatics senior managers and directors of services

- Clinical informatics staff

- ICT staff

- Health records staff.

Of these groups, the report notes (p.9) that the "traditional role of the librarian within healthcare organisations or associated academic institutions has developed, including the greater use of ICT. Librarians are now increasingly seen as Knowledge Managers whose role includes: ascertaining clients' information 
needs, identifying and filling gaps in the provision of useful information, and a distinctive training role. Services may now be delivered through physical or virtual facilities". Of the estimated 20,000 or so staff working in health informatics in England, the report estimates that there are 913 knowledge management staff (and 7,140 ICT staff). The skill areas that are covered by knowledge managers include (p.14):

- Information retrieval (simple and advanced searching) on text databases

- Use of databases and library services to store accredited information that can be accessed electronically (essentially intranets to support evidence based practice)

- Identification and presentation of information suitable for the intended audience, including critical appraisal and evaluation of information and supporting other health staff in critical appraisal skills

- Identifying and collating relevant information to provide targeted current awareness services

- Providing structured training in the use of electronic information resources.

The Knowledge and Skills Framework (KSF) policy document (Department of Health, 2004a) produced by the Agenda for Change Project team, together with the job evaluation handbook (Department of Health, 2004b) provide guidance on the job dimensions used in the NHS KSF, which are divided into six core and 24 specific dimensions. The core dimensions are relevant to every post (Communication, Personal \& People Development, Health/Safety/Security, Service Improvement, Quality, Equality \& Diversity). There are three specific Information and Knowledge dimensions: IK1 Information processing; IK2 Information collection and analysis; IK3 Knowledge and information resources.

At the same time as these developments in the health sector, there were surveys of general library and information skills. The Information Services National Training Organisation Skills Foresight project (2002-2003) assessed the future skill needs of the sector. The skill areas identified (isNTO, 2003) were, unsurprisingly, organised in a different framework to that of the health sector, although there are some similarities. The isNTO framework comprised: External links (environmental awareness, forecasting, influencing); Job related (specialist and IT skills, training skills); Management; and Personal skills. The findings cannot be generalised easily, as the sample was very small, but there are indications that skills associated with research and forecasting are needs underestimated by staff themselves. Leadership, negotiating, managing change, technology awareness and customer care are among the main skills gaps identified.

The report by the Health Executive Advisory Group to CILIP (Health Executive Advisory Group, 2004) was intended not only to set out the agenda for developing health librarians' skills and knowledge for working in the health sector of the future, but also to indicate the needs of the entire profession. Developments in skills for librarianship and information science in the health sector often predate the developments for other sectors, and the report notes that if CILIP does not act wisely and quickly then others will lead the information profession. The report in the section 'Emerging roles and skills' points out that:

- Librarians can, and should, be able to develop specialist skills (e.g. in information retrieval) as a way of gaining promotion as an advanced practitioner - previously the only route was the managerial route

- Team working, in multidisciplinary teams, is more common, and outreach work as a clinical librarian is increasing

- Development and cascading of critical appraisal skills is important

- Rapid decision making can be supported through provision of better quality information

- New services may be developed with a variety of information providers including publishers and public health analysts

- Management of knowledge for clinical governance support, and risk management is becoming more important

- Research skills are vital for librarians if they are to support evidence-based practice. 
The report was based on discussions with health library professionals but it was not based on a systematic review of the evidence.

\section{Methods used for the review of the evidence}

A literature review, using Library and Information Science Abstracts (LISA), identified published articles describing training needs analyses in the health sector (UK and elsewhere). The search terms used were staff development, professional development, medical libraries, health care libraries. Internet searching, plus personal contacts helped to uncover some unpublished studies. The remit was deliberately broad, to identify scoping proposals, workshop events, as well as more formal needs surveys, or evaluations of training support.

The review framework used to collate findings of each discrete UK study comprised:

- Methods used to identify training needs

- Target group (professional staff, paraprofessionals, NHS staff only etc)

- Findings

o Competency framework used in the study (if any)

o Competency framework mapping

o Identified gaps

o Training provided

o Costs of training

o Benefits realisation model

o Evaluation methods

o Link with any accreditation scheme

o Further follow-up.

Most of the studies covered only some of the review criteria. The timescale was 1999-2004, but some earlier UK studies were included as they are relevant to some of the methods currently being proposed for CPD, such as mentoring. The cut-off date for UK studies was therefore 1995, but for 1995-1999 studies only the published literature has was included.

Interviews were sought from Health Libraries Group CPD Panel members, Strategic Health Authority (SHA) library leads, and other expert informants such as NHS Direct personnel,
CILIP Health Executive Advisory Group and the FOLIO team, those involved in UKCHIP (UK Council for Health Informatics Professionals) work. Information was also obtained from the USA on the progress of the specialist 'informationist' roles in the health sector, and further information was obtained from those involved in provision of information for patients and the public through working with patient advisory services.

In all, 18 interviews contributed to the report, together with detailed email responses from Eskind Biomedical Library (Vanderbilt University) on the informationist studies. Some interview data from a previous survey was used, with the permission of the interviewees.

Two workshops were held. The first was in Manchester on 29th November 2004, the second in London on 13th December 2004.

Participants included professional and paraprofessional staff, with 15 participants at the Manchester workshop and 27 participants at the London workshop. In addition, views were sought via mailing lists from those unable to attend the workshops. Prior to the workshop, participants were sent a briefing paper with questions to be considered for the workshop, based on the themes that had emerged from the review of the training needs analyses and the interviews. At the workshop participants worked in small groups (five to seven participants) to consider the questions. The research team, with the help of some NLH staff, acted as group facilitators. After the workshops the responses were collated and then synthesised, together with the individual emailed responses, to highlight the main findings.

\section{Results}

Data from twelve UK studies (listed separately in references) was collated using the framework. The findings were difficult to aggregate or compare as different competencies, and different definitions of competencies had been used (Table 1). The CIPD factsheet (Chartered Institute of Personnel and Development, 2004) defines competency as the behaviours that 
employees must have, or must acquire to input into a situation in order to achieve high levels of performance, while competence relates to a system of minimum standards or is demonstrated by performance and outputs. In practice the two terms are often used interchangeably. The problem, as the CIPD factsheet points out, is that competencies are used to describe two different activities, inputs or behaviours, and the outputs or technical skills. Competency frameworks typically contain a mix of behaviours, functional skills and knowledge. The factsheet also notes that competencies are identified through some form of job analysis using diaries, interviews, observation, critical incident analysis, repertory grids, checklists or some combination of these methods. Identifying future skills needs would, presumably, require some scenario-building to build on identified trends, as the isNTO work has done, using the key change drivers to help identify the skill requirements. Another of the problems in making comparisons is that the level of expertise in most of the frameworks is not clear, although the SW study and the South Yorkshire study did ask participants to assess their level of expertise in some of the skills and knowledge areas.

\begin{tabular}{|c|c|c|c|c|}
\hline LISU & $\begin{array}{l}\text { Lacey \& Booth } \\
2003\end{array}$ & $\begin{array}{l}\text { South Yorkshire } \\
\text { study } 2004\end{array}$ & London study 2004 & SW study 2003 \\
\hline $\begin{array}{l}\text { General } \\
\text { librarianship and } \\
\text { information work }\end{array}$ & Professional skills & Specialist & $\begin{array}{l}\text { Information retrieval } \\
\text { and database } \\
\text { searching } \\
\text { Others subdivided } \\
\text { into other categories }\end{array}$ & $\begin{array}{l}\text { Information } \\
\text { management }\end{array}$ \\
\hline $\begin{array}{l}\text { (includes current } \\
\text { trends, standards, } \\
\text { publishing, and KM) }\end{array}$ & $\begin{array}{l}\text { Contextual } \\
\text { knowledge }\end{array}$ & $\begin{array}{l}\text { Underpinning } \\
\text { knowledge }\end{array}$ & $\begin{array}{l}\text { Legislation } \\
\text { awareness }\end{array}$ & \\
\hline Health sciences & NHS context & $\begin{array}{l}\text { Underpinning } \\
\text { knowledge }\end{array}$ & $\begin{array}{l}\text { NHS policies and } \\
\text { developments, } \\
\text { awareness }\end{array}$ & $\begin{array}{l}\text { Awareness of NHS } \\
\text { policies, activities }\end{array}$ \\
\hline $\begin{array}{l}\text { Technical } \\
\text { (mainly ICT, } \\
\text { Intranet, hardware } \\
\text { \& software) }\end{array}$ & Technical & $\begin{array}{l}\text { Technical } \\
\text { Specialist }\end{array}$ & ICT skills & $\begin{array}{l}\text { ICT skills } \\
\text { (includes database } \\
\text { searching, Internet } \\
\text { searching) }\end{array}$ \\
\hline $\begin{array}{l}\text { Financial and } \\
\text { management }\end{array}$ & Managerial & $\begin{array}{l}\text { Included in } \\
\text { underpinning } \\
\text { knowledge, and } \\
\text { interpersonal skills }\end{array}$ & $\begin{array}{l}\text { Business } \\
\text { management, } \\
\text { Financial } \\
\text { management, } \\
\text { Personnel } \\
\text { management }\end{array}$ & $\begin{array}{l}\text { Business skills } \\
\text { Includes marketing, } \\
\text { negotiating } \\
\text { influencing }\end{array}$ \\
\hline $\begin{array}{l}\text { Training/ } \\
\text { marketing/ research }\end{array}$ & $\begin{array}{l}\text { Learning \& } \\
\text { teaching } \\
\text { Marketing with } \\
\text { Managerial, and } \\
\text { Research classified } \\
\text { as Technical }\end{array}$ & $\begin{array}{l}\text { Specialist and } \\
\text { interpersonal }\end{array}$ & $\begin{array}{l}\text { Teaching and } \\
\text { training, } \\
\text { Research support }\end{array}$ & Training and HR \\
\hline $\begin{array}{l}\text { Personal } \\
\text { characteristics }\end{array}$ & Interpersonal & Interpersonal & Customer handling & $\begin{array}{l}\text { Communication } \\
\text { and presentation } \\
\text { Also included in } \\
\text { Business skills }\end{array}$ \\
\hline
\end{tabular}

Table 1 Competency and skills framework mapping 
The common themes in identified skills gaps were in:

- Technical and ICT skills (from web page design in 1999 to knowledge management skills to support intranets in 2003)

- Teaching skills (with indications that the needs of the emerging specialist trainer role will differ from the needs of the generalist, informal support)

- Research and analytic skills (quantitative and qualitative data analysis skills, critical appraisal and statistics)

- Customer care skills (increasingly the need to cater for the virtual customer)

- Leadership and strategic planning skills (influencing and persuading skills, political awareness).

Many of the studies were based on subjective estimations of library staff themselves, and only a few studies attempted to identify some training needs that were unrecognised, but present. For the NLH research, a policy overview for the S. Yorkshire study (Urquhart, Durbin \& Spink, 2004) indicated the increasing importance of 'patient choice', and information for the patient, and initiatives include the development of NHS Direct, NHS Direct Online. None of the training needs analyses mentioned dealing with patient information but this lack reflected the historical organisation of library and information services in the health sector, with few links between the services funded for health staff or student use, and services devoted to patients and consumers.

Interviews helped to explain some of the uncertainties about the skills gaps, but generally interviewees agreed with the literature review indications. For example, some of the training provision needs to be graded, or at least staged, so that staff can choose the appropriate level for their roles. This applies, for example, to the teaching/training skill set.

maybe even some basic stuff around making people feel welcome and what they used to call reference interviews and finding out, and then you could move onto... at the top there's the whole planning lessons, learning outcomes, the whole raft of skills that you need to be an effective teacher.
In some areas considerable emphasis is placed on the teaching skills of library staff.

Also, something we're pushing quite hard is the teaching qualification - whether they do the City \& Guilds adult education qualification, or whether they do the basic skills education or the ordinary PGCE - that's a big strand for us - so your basic librarianship qualification must teach you to be a good teacher!

Knowledge management is partly about setting up knowledge exchange databases but there is probably a need for a strategic approach to knowledge management beyond upgrading library staff skills.

there is clearly a need for some work to be done to support how we develop those (knowledge management) skills in not only library managers I guess but more broadly within staff as a whole...certainly trying to build these ideas of communities of practice... supporting people in spreading good ideas and sustaining good practice.

The biggest skills gap I think is around leadership and management - change management and negotiation skills...Those knowledge management, business related skills, understanding the organisation and being able to manage change, being able to provide leadership, there's a huge gap there.

Others stressed the need to develop the traditional classification skills, to extend those for intranets, and appreciate other approaches to medical thesauri and controlled vocabularies than MeSH (Medical Subject Headings) used by MEDLINE.

Content management is...going to be a really good role that librarians could fit into and should fit into...possibly helping to manage intranets or huge websites and the ability to put local, regional, national and international content into perspective is going to be important....you can't force people just to go to one place and in fact it's good for people to go to more than one place and compare what they find.

I think librarians needs to learn a bit more about controlled vocabularies...SNOMED...ICD...UMLS. 
The main findings of the workshops concerned views on: professional accreditation; delivery of training; use of e-learning; mentoring, buddying and coaching; and career pathways. Participants noted that CILIP membership was not valued by NHS employers (although this may alter with Agenda for Change job profiles) and several expressed doubts that the new CILIP framework would meet the needs of the specialist librarian staff. Awareness of UKCHIP activities was low, but most acknowledged the possibility that NHS-wide recognition of membership of an 'informatics' profession would be useful. Training delivery needs to be varied, and while e-learning is very useful for some purposes, workshop participants demanded more variety in location and format, with suggestions for cross-sectoral training, and more emphasis on supporting new skills acquired in training through to practice. Mentoring was valued, although participants warned about the dangers of passing on bad habits, and emphasised the need for mentor training. Coaching, often by staff in other professions, was valued for support in developing leadership skills.

On emerging career pathways, participants agreed with the HEAG report that there was more emphasis on specialist skills, on outreach, and more working outside the physical library for professional staff. Inevitably, that meant that paraprofessional staff were taking on roles previously undertaken by professional staff, and training provision should reflect that.

\section{Discussion}

Much of the evidence confirmed the forecasts of the HEAG report, that librarians in the health sector could and should develop specialist skills in information retrieval, or in work as a clinical librarian, supporting multidisciplinary health professional teams. Many of the skills gaps, such as the need for better quantitative data analysis skills, or leadership skills, are not new or confined to the library and information sector. Some of the needs for specialist skills in health information are reflected in the work in the USA, to develop the 'informationist', (Detlefson, 2002) a clinical health information professional with added qualifications, gained either through graduate education or experience. Further work is now delineating the roles of the informationist/information specialist in context (Medical Library Association, 2005).

Synthesising some of the other skills gaps reveals an iceberg called numeracy. Librarians want to be able to write successful bids, to manage projects, to evaluate their services through performance measurement and benchmarking, support critical appraisal training, and evidence-based practice, but their lack of skills in handling quantitative data is a major hurdle. The LISU report (Maynard et al., 2000) (Maynard, 2002) noted that librarians did not themselves recognise that they lacked these skills - a case, perhaps, of you don't want to know what you don't want to know. In the health sector, having a scientific background provides a good confidence boost at the start of a career in the health sector (Dukic-Petrinic, 2005). Fourie (2004) suggests that librarians need to reposition themselves, and should scan the environment carefully, but nevertheless, librarians may need some underpinning knowledge to take advantage of opportunities when they occur. Confidence may require some basic competence, and the chance to practise and develops new skills in a safe environment. The training needs analysis for South Yorkshire (Urquhart, Durbin \& Spink, 2004) indicated that library managers spent very little time on tasks that might be considered practice of leadership skills. As Abbott (2003) suggested, the problem is not the lack of opportunities for formal training in such skills. Managers need support through coaching to develop leadership skills after the initial training. Similarly, the critical appraisal, and research skills may need practice to build not just competence but the necessary confidence in quantitative data analysis. There should be more emphasis on capability in CPD programmes, to develop expertise, and the personal competencies as set out in the Special Libraries Association revised competencies for information professionals (Special Committee on Competencies for Special Librarians, 2003).

The Museums, Libraries and Archives Council (MLA) workforce development strategy (MLA, 2004) recommends that the key areas in 
developing the workforce included leadership, business management, and ICT skills. They note a mismatch between employer needs and higher education outcomes. That mismatch can be tackled in several ways: by recruitment from a different pool, by changes to the curriculum in library and information studies departments, or by different strategies for CPD. Most probably, a combination is required. The undergraduate subject benchmark statement for library and information management (QAA, 2000) does not imply specific skills in quantitative data analysis beyond 'a grounding in research methods', and the ability to 'manage data and present results in an appropriate manner'. There are few postgraduate benchmark statements, but the statement for MBA courses (QAA, 2002) notes that graduates should demonstrate 'numeracy and quantitative skills, including the use of models of business situations; qualitative research skills'; as well as 'leadership and performance management'. For higher education institutions, preparing students for entry into work in the profession, a compromise between specialist and general management skills may be necessary, but there should be opportunities to support the development of more specialist skills in CPD programmes.

\section{Conclusion}

The research for the NLH highlighted the problem of collating findings from training needs analyses that have used different competency frameworks. This is likely to be a difficult problem to resolve as the type of specialist skills required are changing so rapidly, but local training needs analyses could use a nationally recognised framework as an outline.

Many of the skills gaps revealed in the research for the NLH were not new, but current manifestations of longstanding problems in the sector. Further analysis suggests that more coaching is required to develop the necessary leadership skills, but that there is an underlying problem with numeracy that needs to be tackled if managers in the sector are going to apply research skills, manage finances, and evaluate performance successfully.
Further research is necessary to examine how best the scaffold existing competencies to the capabilities required for the future. The MLA workforce development strategy (2004) noted the lack of adequate workforce data in the sector, and that is the basis of any proper detailed strategy for workforce development planning. The NLH research noted the need to use strategies such as action learning to practise and develop newly acquired skills, but also stressed the need for variety in training provision. The emphasis should move as quickly beyond competence to capability.

\section{References}

Abbott, C. (2003). HIMSS (Hybrid Information Management: Skills for Senior Staff) Final project report. HEFCE 99/54: Good Management Practice GMP I 28. Birmingham: University of Birmingham, http://www.himss.bham.ac.uk [accessed May 2005]

Chartered Institute of Personnel and Development. (2004). Competency and competency frameworks. Factsheet. London: CIPD.

Christie, M. (2004). Project to develop national occupational standards for health informatics 2003-2005. Occupational map for health informatics. (8th version, draft material ed.).NHS Information Authority.

Department of Health. (2002). Making information count: a human resources strategy for health informatics professionals. London: Department of Health.

Department of Health (2004a). The NHS knowledge and skills framework and related development review process. London: Department of Health.

Department of Health. (2004b). NHS job evaluation handbook (2nd ed.). London: Department of Health.

Detlefson, E. G. (2002). The education of informationists, from the perspective of a library and information sciences educator. Journal of the Medical Library Association, 90(I), 59-67.

Dukic-Petrinic, T. (2005). Personal communication (research for MSc dissertation, University of Wales Aberystwyth).

Fourie, I. (2004). Librarians and the claiming of new roles: how can we try to make a difference? Aslib Proceedings $56(\mathrm{I}), 62-74$. 
Systematic assessment of the training needs of health library staff C. Urquhart, S. Spink, R. Thomas, J. Durbin

Health Executive Advisory Group. (2004). Future proofing the profession: the report of the Health Executive Advisory Group to the Executive Board of CILIP. London: CILIP.

is NTO. (2003). Future skills needs and sources for libraries, archives and records management: postal questionnaire (Skills Foresight Project 2002-3 is NTO (Information Services National Training Organisation).

Medical Library Association (2005).

Informationist/Information in Specialist Context concept. Available from:

http://www.mlanet.org/research/informationist/index.ht $\mathrm{ml}$ [accessed October 21, 2005]

MLA (Museums, Libraries and Archives Council) (2004). Learning for change: workforce development strategy. London: MLA.

QAA (Quality Assurance Agency for Higher Education) (2000, 2002). Subject benchmark statements.

Gloucester: QAA. Available from:

http://www.qaa.ac.uk [accessed October 2005]

Special Committee on Competencies for Special Librarians. (2003). Competencies for information professionals of the 2 Ist century. Revised edition, June 2003. Special Libraries Association. Available from: http://www.sla.org/content/learn/comp2003/index.cfm [accessed May 2005]

Urquhart, C, Durbin, J and Spink, S. (2004) Training needs analysis of healthcare library staff. Undertaken for South Yorkshire Workforce Development Confederation. Available from: http://users.aber.ac.uk/cju

Urquhart, C, Spink, S and Thomas, J. (2005) Assessing training and professional development needs of library staff. Research undertaken for the National Library for Health. Available from: http://users.aber.ac.uk/cju

\section{List of training needs analyses reviewed}

Cox, R. (1995). Assessing the training needs of library staff in the South Thames (East) Region. Health Libraries Review, I2(I), 55-58.

Davies, C. (2004). Acting nationally, thinking locally. Opportunities Consultation Group Report. Warrington: Health Care Libraries Unit NW.

Kitch, P. (1995). A framework for continuing professional development in the South West Region. Health Libraries Review, I2(I), 58-60
Lacey Bryant, S. (2003). NeLH outreach librarian support and development project: the findings of a survey of 'outreach librarians.' Available from Doctors net uk.

Lacey, T., and Booth, A. (2003). Education, training and development for NHS librarians: supporting e-learning. A review commissioned by the National electronic Library for Health Librarian Development Programme. Sheffield: University of Sheffield, ScHARR (School of Health and Related Research).

London Health Libraries Strategy and Development Group. (2004). London Health Libraries Training Needs Analysis 2004: summary report. London: London Health Libraries Strategy and Development Group

Maynard, S. (2002). The knowledge workout for health: a report of a training needs census of NHS library staff. Journal of Librarianship and Information Science, 34(I), I7-32.

Maynard, S., Kinnell, M., White, S., and Yu, L. (2000). Training needs census of NHS library staff. Loughborough, University of Loughborough: Library \& Information Statistics Unit.

Palmer, J. (1997). The twenty-first century is here. Library Association Record 99(6), 3 I5-317

Pearson, A. and Urquhart, C. (2002). Health informatics education - working across the professional boundaries. Library Review, 5 I (3/4), 200-2 10

TFPL. (2003). Developing knowledge management competencies in the NHSSW (personal communication)

Urquhart, C., Durbin, J. and Spink, S. (2004) Training needs analysis of healthcare library staff. Undertaken for South Yorkshire Workforce Development Confederation. Available from http://users.aber.ac.uk/cju

Whittlestone, R., Low, B.Y. M., and Pope, A. (1999). Partnerships for the new NHS. Library Association Record, I0I(I2), 704-705 